\title{
Bottom-up or top-down? The origins of the Industrial Revolution
}

\author{
JOEL MOKYR* \\ Department of Economics and History, Northwestern University, USA, and Berglas School of Economics, Tel Aviv \\ University, Israel
}

\begin{abstract}
Was technological progress during and after the Industrial Revolution top-down or bottom-up? The technology that created the great inventions was driven by a combination of pathbreaking ideas and the dexterity and skills of trained artisans. While those forms of human capital were quite different, they both came out of small elites of intellectuals and craftsmen, what are rapidly becoming known as "upper-tail human capital." I analyze the institutions that drove the incentives for both, and show that they came together to produce the Great Enrichment. These incentives were both material and social: between 1500 and 1700, the search for financial security and reputation cooperated in producing a unique institutional environment in which the elites in Western Europe produced the three legged-stool of European modernity: the Reformation, the Scientific Revolution, and the Enlightenment. Once these three movements had succeeded, the foundation for modern economic growth had been laid.
\end{abstract}

\section{Introduction $\$$}

Whether we like it or not, elites mattered in economic history. Throughout history, they helped to set up institutions and define the rules of the game of the economy: priests and kings wrote the laws, and judges and generals enforced them. The voice of the people may be the voice of God, as the Romans had it, but they rarely determined outcomes. Acemoglu and Robinson (2006), in their classic analysis of the emergence of institutions, distinguish between de jure power (the power of the law), which is mostly in the hands of elites and de facto power exercised by larger groups, which operates more as a constraint on those running the day-to-day business.

Yet while the masses could still on occasion matter a lot in exercising political power by overthrowing a ruler and changing political regime, on the matter of technological progress and intellectual innovation - as opposed to the routine

\footnotetext{
*Email: J-Mokyr@northwestern.edu

$\mathbb{S}$ This paper was presented to the symposium Innovation and Creative Production: "Innovation from the Bottom-Up," New York University, December 6, 2016. Some of the below is adapted from my $A$ Culture of Growth: Origins of the Modern Economy, Princeton: Princeton University Press, 2016. I am indebted to Ashish Aggarwal for research assistance, and the Balzan Foundation for financial support.
} 
performance of production tasks - we are confined to what is now increasingly known as "upper-tail human capital," that is, the skills and knowledge of the best scientists, artisans, engineers, mechanics, and physicians. ${ }^{1}$ In a famous prophetic line, the great $17^{\text {th }}$-century scientist and experimentalist Robert Hooke wrote that the world of useful inventions remained to be conquered by "a Cortesian army, well-Disciplined and regulated, though their numbers be but small" (cited in Hunter, 1989: 233). ${ }^{2}$ The metaphor illustrates well the idea that the envelope of useful knowledge is pushed forward by a relatively small number of people.

The notion that economic growth driven by advancing knowledge is a topdown mechanism was expressed equally well by Adam Smith when he noted that "to think or to reason comes to be, like every other employment, a particular business, which is carried on by very few people who furnish the public with all the thought and reason possessed by the vast multitudes that labour." The benefits of the "speculations of the philosopher ... may evidently descend to the meanest of people" if they led to improvements in the mechanical arts (Smith [1762-3] 1978, pp. 569-72). ${ }^{3}$

That said, there is no question that we should be careful to avoid the kind of hero-worship that Victorian writers of the Industrial Revolution such as Samuel Smiles at times engaged in. The great inventors whose names are immortalized in Smiles' books and modern biographical dictionaries depended on hundreds of lesser-known and unknown ingenious artisans and engineers who made the micro inventions that tweaked and adapted the bigger breakthroughs and made them work better and break down less. ${ }^{4}$ Below those, there were thousands of largely anonymous workers whose skills and competence turned prototypes and blueprints into actual working machines, who read and interpreted instructions contained in the new recipes, who scaled up models, and who had the capabilities needed to install, operate, and repair the equipment embodying the new technology (Meisenzahl and Mokyr, 2012).

There is a deep complementarity between the small group of people who actually invented things and can be identified as such, and the larger group of skilled workmen, who could build the designs with low tolerance (that is, at a high level of precision), and could fill in the blanks. If we think of a

1 The term was proposed in Mokyr (2005: 1157; 2009: 122). For a recent application see Squicciarini and Voigtländer (2015); for a demographic analysis of "famous people" see de la Croix and Licandro (2015).

2 The reference to the conquest of Mexico by Spanish looters as a form of progress may strike us today as quaint, but in the era of Hooke it was clearly seen as a step forward.

3 Smith's remark is especially remarkable because in his time there were relatively few examples of ideas from natural philosophy directly triggering technological advances, though he clearly was aware of steam engines (([1762-3] 1978): 326).

4 A demonstration of this process in the $18^{\text {th }}$-century British watch industry is provided by Kelly and Ó Gráda, 2017, who show a continuous rise in productivity despite the absence of any game-changing macro inventions. 
technique as a "recipe," that is, a list of instructions on how to make something, these instructions were inevitably incomplete and hence tacit knowledge was essential. Many new technological designs came about through small, cumulative improvements made by mostly unknown craftsmen and diffused through the networks of technically literate masters and journeymen who became increasingly adept at disseminating tacit knowledge. Indeed, some scholars (e.g. Berg, 2007; Epstein, 2008) have argued that these advances were the core of technological progress before the Industrial Revolution. During the Industrial Revolution itself, the role of formal knowledge and what we would call science may have been larger (Jacob, 1997; Musson and Robinson, 1969), but the exact importance of this role is still a matter of considerable controversy (Mokyr, 2009 , chapter 3). In a sense, the "top-down or bottom-up" dichotomy is a red herring, because it was both the very top scientists and engineers and the skilled and trained artisans who made technological progress happen. Yet it remains true that the contribution of the bulk of the labor force remains modest, and hence the average rate of literacy or education may have mattered but little at the early stages of the Industrial Revolution.

Be that as it may, the people who were advancing the technological frontier remained a small minority, and technology-driven economic development can be viewed as resulting from their actions (Mokyr, 2009: 39; 2016, chapter 6). Inventions eventually affected the economic status of the rest of the population, not so much by a trickle-down as a dragging-along process. ${ }^{5}$ Yet highly skilled artisans could not by themselves bring about technological revolutions, even if they could adapt and improve existing techniques up to a point. At times what was needed was a crucial and radically novel insight into the way natural forces operated.

The exact modus operandi of this top-down mechanism varied greatly from situation to situation. The socio-economic elites (the nobility and well-to-do bourgeoisie) of early modern Europe acquired education, studied science, and read books, and others followed and imitated them. It is not surprising that intellectual innovations were aimed first at educated people who could access them using printed sources or letters or by attending lectures. They were therefore more likely to be persuaded by new information and less committed to the ideas they were socialized with: those of their parents or of teachers reflecting their parents' beliefs. However, greater exposure to new information and ideas opened doors; it did not force anyone to walk through them. Educated people might indeed have had a vested interest in adhering to the ideas they learned early in life and many resisted radical change. Much of the conservative elite educational structure of the time - not least the mostly conservative universities and Jesuit schools - was

5 For instance, the flying shuttle, invented by the reed-maker John Kay in 1733, was widely adopted (after a few decades) in the British cotton and woolen industries, despite loud protestations by hand loom weavers as it demonstrably made the weaving process more efficient. 
still faithfully reproducing traditional knowledge embodied in the classical canon, and was resistant to new ideas to the point of imperviousness. Yet in the long run, the venerable ideas and techniques that had been in use for countless generations had to make room for the intellectual innovations of the age.

What counted disproportionately in the fateful centuries that preceded the Industrial Revolution in Western Europe, then, was the changing culture of an educated elite and the institutions that it shaped and was shaped by. ${ }^{6}$ As noted, advances in useful knowledge were made by a relatively small percentage of the population. Social and political institutions steered their behavior by setting incentives, both positive (rewards) and negative (penalties). Once acquired, the attitudes and aptitudes of a better-informed and more practical and materially oriented elite eventually affected larger and larger segments of the population (Mokyr, 2017). In the early stages of modern economic growth, a combination of brilliant craftsmen and daring scientists came up with the technological breakthroughs we associate with the Industrial Revolution. They were fortunate to find themselves in the company of highly skilled artisans and dexterous engineers, who were able to carry out their ideas, scale them up, and thus bring about the progress that changed history. While these two groups differed in culture and education, they were both very much in the upper tail of the human capital distribution.

Technological innovations before 1750 came from a different kind of elite: top-level artisans, mechanics, and dexterous technicians. Their world was primarily a world of practical people, not theoreticians, but the worlds of savants and fabricants overlapped increasingly in early modern Europe. On the one hand there were natural philosophers who had the capacity to build their own equipment and instruments, of whom Robert Hooke and, a century later, Pierre-Simon Laplace are the most prominent examples. On the other hand there were artisans with a relatively poor formal education, who realized that there was something to learn from people with more theory than themselves. Thus, for instance, the inventor of the puddling and rolling process Henry Cort, who apparently had no scientific training, consulted the best scientists in Great Britain. ${ }^{7}$ Many of the great and lesser figures in the Age of Enlightenment straddled both worlds. ${ }^{8}$

6 The distinction I propose between "culture" and "institutions" is that culture refers primarily to beliefs and preferences, whereas institutions are the Northian rules of the economic game that shape incentives and thus guide behavior. For more details, see Mokyr (2016, pp. 9-11).

7 Joseph Black, the leading British physicist of his age, wrote to his friend James Watt that Cort was "a plain Englishman, without Science" whose discovery was due to "a dint of natural ingenuity and a turn for experiment" (cited by Coleman and MacLeod, 1986: 603). Yet Cort took the trouble to consult him, recognizing that if Black might know things that were relevant to his work, it made sense to ask him about them.

8 Some of the great scientists of the 18th century made significant inventions, such as René Réaumur, who invented a new form of porcelain and a cupola furnace, and Joseph Priestley who invented carbonated water. 
Technological creativity involved both utilizing existing knowledge and its negation - that is, the willingness to look critically at existing practices and knowledge and think "outside the box." Such willingness to challenge conventional wisdom was rarely a common trait in past societies. Through most of history, societies encouraged respect for the knowledge of earlier generations, and punished heresy. Every invention was, by definition, an act of disrespect. All the same, as long as there are enough non-conformist, contrarian, and arrogant individuals who have the willingness and ability to go against the grain, and as long as the political institutions are sufficiently friendly so that "deviant thinkers" do not have constantly have to be concerned about being charged with "heresy," black magic, or some other form of non-conformist persecution, there is a good chance that radical departures in science and technology will occur. Economies may experience economic progress as a consequence. Yet the conditions for such economic progress to occur and be sustained are rather strong and many disparate institutional elements have to come together at just the right time to make sure that radical innovation can thrive and start a self-sustaining process of progress that does not eventually fizzle out. It is not surprising that they only occurred once in history. What is perhaps more surprising is that they occurred at all.

\section{Prelude to the Industrial Revolution}

Developments in Europe in the centuries before the Industrial Revolution were in many ways decisive in bringing it about: nobody really thinks that the wave of technological advances that began in the 18th century were a freak event, in which they descended upon Europe like a sudden thunderbolt. But which developments in the previous centuries really counted? Many have pointed to institutional changes that created better property rights, improved the rule of law, and imposed less extractive governance due to constraints imposed on rulers. Others have pointed to European expansion after 1450 and the growth of "ghost acreage" and "ghost labor" in overseas continents, including slavery, sugar, raw cotton, and the growth of long-distance commerce. ${ }^{9}$ Explorations in the New World and trade with the East exposed Europe to certain goods and techniques such as tobacco, potatoes, cotton cloth, and chinaware. Technological progress was supposedly triggered by import substitution or high wages. Religion and the Protestant Reformation have also been credited, both in the original Weberian formulation and more sophisticated versions of it.

Three recent works in economic history, Clark (2007), Mokyr (2009), and McCloskey (2010) have - in very different ways - surveyed the array of explanations as to why the Industrial Revolution occurred in the 18th century in

9 For a recent restatement of the predatory interpretation of European growth, see especially Beckert (2014). 
Western Europe and not some other place and time (or never at all) and found almost all of them wanting. Both Clark and McCloskey emphatically reject any explanation that relies on institutions, although these rejections depend on somewhat narrow definitions, at odds with the much richer definitions suggested for instance by Greif (2005) and many other scholars following the seminal work by Douglass North. ${ }^{10}$ All three works in the final analysis fall back on a cultural explanation of sorts, though they postulate very different mechanisms for what is driving innovation. Strikingly, Clark and McCloskey, despite their differences, focus on the cultural attributes of relatively small elite groups. ${ }^{11}$

The effect of elites and their beliefs on the subsequent development of the economy has many dimensions. For one thing, political and social elites (as distinguished from intellectual and artisanal elites) often set the hierarchy of values in society. The nobility set norms and values that middle-class people wanted to emulate in the best traditions of the bourgeois gentilhomme. As has often been pointed out, in extractive societies dominated by a small, wealthy, but unproductive and exploitative elite, the low social prestige of productive activity meant that creativity and innovation would be directed toward an agenda that was of interest to the elite but rarely conducive to economic growth. Through much of history, educated and sophisticated oligarchies focused their efforts and time on supporting their power over the majority by emphasizing activities such as military prowess and administration (as was the case in the Roman Republic), or on such aristocratic topics of leisure as literature, games, the arts, and philosophy, and not so much on the mundane problems of the farmer in his field, the sailor on his ship, or the artisan in his workshop. ${ }^{12}$ In early modern Europe the chasm that had separated social and political elites from knowledge elites began slowly to narrow. It never disappeared altogether, but once the gap was narrow enough, it could be bridged.

One of the more significant changes in the centuries before and during the Industrial Revolution was a profound cultural change that affected Europe's upper classes in the late Middle Ages and especially the centuries book-ended by Columbus and Newton, namely the rise of the value of science and technology in the hierarchy of social prestige of the elites. Many of the powerful and rich felt it appropriate to sponsor and support learned people at their courts, none more so than the otherwise rather hapless Habsburg Emperor Rudolf II (Evans,

10 For a more detailed criticism of McCloskey's attack on institutions as a force for historical change, see Greif and Mokyr (2016).

11 Clark focuses on those relatively better-off members of the middle class who reproduced at a faster rate and transmitted their growth-enhancing features to their more numerous offspring. McCloskey focuses on those with bourgeois values and bourgeois ethics, and while she never quite measures the size of that group, it presumably included but a minority of the population.

12 The agenda of the leisurely elite was of great importance to the lovers of music in the 18th-century Habsburg lands, but was not of much interest to their farmers and manufacturers. The Austrian Empire created Haydn and Mozart, but no Industrial Revolution. 
1973). Some of the great scientists of the age belonged to the social elite, some of them by birth, others by economic status. Beside Bacon himself, one thinks of Robert Boyle, who was the scion of one of the richest families in England, or Antoine Lavoisier, the son of a wealthy aristocratic lawyer and member of the Paris Parliament, the chemist Henry Cavendish (the grandson of the Duke of Devonshire), or the Scottish experimentalist Archibald Cochrane, the Earl of Dundonald. Ferdinando de Medici, grand duke of Florence and Galileo's patron, is credited with the invention of a substantially improved thermometer in the mid17th century. Of course, members of the aristocratic elite were active in other intellectual pursuits besides natural philosophy, as attested by philosophers such as Shaftesbury and the Baron d'Holbach. ${ }^{13}$ The idea of natural philosophers and great engineers as role models and people of high social-status whom young and ambitious persons would want to imitate took a long time to form, but at least two giants in British history, Newton and Watt, managed to achieve exactly that (Fara 2002; MacLeod, 2007). On the continent things were moving along the same lines. In early 18 th-century France, the new science was especially valued and became part of high society and a new political culture in which a powerful alliance was created between the savants of the Republic of Letters and the royal administration (Shank, 2008: 88). ${ }^{14}$ The Dutch physician Herman Boerhaave was so famous in his time that Peter the Great sat in on his classes and Voltaire and Linnaeus traveled to Leyden to meet him. ${ }^{15}$ The effective allocation of talent and human capital in the extreme upper tail of the distribution of talent was sensitive to such signals.

Yet the Industrial Revolution was not made by superstars alone. As noted, the trained mechanics and engineers who read blueprints, scaled up models, and tweaked and implemented the new techniques made the Industrial Revolution possible. They came from a variety of backgrounds, of course, and their training and education differed. Most, but not all, were literate and educated to

13 One symptom of a cultural change in Europe was the emergence in the 17th century of a peculiar upper-class trend known as "virtuosity" - a word that meant something quite different in early modern Europe than it does today. Originally a product of Italian courts and heavily influenced by Italian norms of behavior, it depicted an upper-class fascination with learning and the arts, combining the features of scholar and gentleman into a serious if perhaps somewhat amateurish intellectual. But the virtuosi provided much-needed respectability to those who contemplated engaging in intellectual endeavors and they turned curiosity, once regarded as a vice, into a virtue (Houghton, 1942). Whether the virtuoso movement as a whole was a success in reforming the views of the British aristocratic elite and turning them into a building block of the Industrial Enlightenment remains an open question. There was a continuous gradation from leisurely and possibly bored wealthy gentlemen who played with science (such as Boyle and Evelyn) to the serious (if often impecunious) professional natural philosophers such as Ray and Hooke.

14 Shank explains that royal administrators saw academics as a model and a catalyst for bringing about a wider transformation of French society, but the social boundary between savants and royal officeholders was often quite blurry.

15 A possibly apocryphal story has it that a letter sent from China by a Mandarin, addressed simply to "the illustrious doctor Boerhaave, physician in Europe," reached him without delay. 
some extent, either through apprenticeship or formal schools (Meisenzahl and Mokyr, 2012). ${ }^{16}$ Others were intuitive mechanical geniuses without much formal education. ${ }^{17}$ High-quality artisans were a necessary part of the technological revolutions, but they were not enough. Without new and often radical ideas about how nature worked, artisanal ingenuity would have run into diminishing returns and eventually progress would have ground to a halt as happened in the high-level artisanal economies of the Middle East and South Asia (Berg, 2007; Mokyr, 2007). Conceptual breakthroughs were needed for such radical inventions as steam power and gas lighting. ${ }^{18}$ Hydraulic engineering was another case in point. ${ }^{19}$ Thus, modern economic growth was the outcome of the collaborative efforts of two elites, a small groups of savants and a larger (but still smallish) group of fabricants, and the interaction between them in the best traditions of the Baconian program. ${ }^{20}$

The degree to which economic history is driven by a "vital few" and their indispensability has been controversial. Most modern historians have tended to dismiss the impact of individuals on history by mocking the "intellectual prowess and persuasive capabilities of a few men" and stressing cultural change as "a confluence of available ideas," although one is left wondering where such

16 One striking finding is that in this respect textiles were quite different from other trades, and that high-quality technicians in that sector had relatively little formal education, unlike other sectors in the Industrial Revolution. This should serve as a warning that generalizations about the Industrial Revolution based largely on the experience of the cotton industry (Allen, 2009) may be unsupportable.

17 George Stephenson, the co-inventor of the mining safety lamp whose Rocket won the Rainhill Trials, was entirely self-trained in engineering skills, had very little math and almost no writing skills, and needed to hire a secretary to write his letters for him.

18 The connection between the development of gas lighting and formal science is the topic of Leslie Tomory's (2012) excellent book. The scientific basis for the controlled burning of gases was pneumatic chemistry, a branch of science that went back to van Helmont in the early 17 th century. It was taken further by giants of the Industrial Enlightenment such as Joseph Black, Antoine Lavoisier, and especially Alessandro Volta.

19 The understanding of water power presented the kind of give and take between science and technology that the Baconian program suggested. Yet it also serves as a good illustration of the highly erratic and non-linear trajectory of the much-touted interplay of theory and practice. The original mathematical work by Antoine Parent, which applied the newly invented calculus to the flow of water, contained a number of errors first pointed out by Daniel Bernoulli in the 1730s (Pacey, 1975, pp.88-9; Reynolds, 1983: 207). It took many more decades to straighten out the theoretical basis of water power, and the path-breaking work on hydraulics by the French mathematician Jean-Charles de Borda (1733-99) remained unrecognized for many years.

20 The Baconian program, the ideology that formed the backbone of the industrial Enlightenment, consisted of three components. First, scientific research should expand humanity's knowledge and understanding of the universe. By accelerating the pace of research into natural phenomena that had long been of interest, armed with better research equipment and scientific method, nature could be harnessed to serve people better. Second, the research agenda should be directed to areas where there was a high chance of solving practical problems - in medicine, manufacturing, navigation, and so on. Third, the access costs to this knowledge should be made as low as possible, not only by dissemination but also by organizing and classifying what was known, so as to maximize the chance of it being applied in productive manner (Mokyr, 2009: 40). 
influential ideas might have come from in the first place (Lowengard, 2006: 6). In contrast, Jonathan Hughes (1986: 2) wrote that "to ignore the impact of individuals on our historical development would be like studying physiology without considering the actions of the organs and cells on the body and each other." ${ }^{21}$ Technological advances and the harnessing of best-practice science to the needs of industry in the period of the Industrial Revolution was a minority affair even with the industrial community. Unlike such pro-science entrepreneurs such as Matthew Boulton, Jedediah Strutt, his son William Strutt, and Josiah Wedgwood, most British entrepreneurs and industrialists of the time were not part of the Industrial Enlightenment and had little knowledge of or interest in science or even innovation, just as most landowners were not improvers. But the dynamics of competition in a market economy are such that in the long run, the few drag along the many. Yet competition and markets do not explain what it was that motivated and incentivized the pivotal minority that drove the historical dynamics in the first place.

\section{Positive and negative incentives}

Economists teach that people are motivated by incentives and that institutions matter because they set incentives. Contrary to some popular opinion, they do not believe that people are only driven by greed. But people, and even scientists and philosophers, have to eat. Making ends meet and working in a financially secure environment clearly matters to intellectuals. For a few, the chance of striking it rich is a powerful incentive. However, as is widely recognized, the production of new knowledge is severely under-incentivized simply because knowledge is nonexcludable, that is, it cannot be fenced in: once the original creator has shared it with another person, she has lost control over its further dissemination. As a result, there is a serious danger that knowledge will be systematically underproduced - the people who generate it cannot expect to be paid for their troubles and expenses. Indeed, knowledge shares many of the features of the commons (Ostrom and Hess, 2007). Much like a commons, knowledge is a shared resource, but one that is produced in the system and has a positive opportunity cost. Unless people can be somehow charged for its use, at first blush no one has any financial incentive to produce it. The putative "tragedy of the commons" suggests that any system of knowledge production would flounder on the non-excludability of knowledge. And yet, just as commons do not always become a tragedy but can be managed by a community, knowledge production can be properly incentivized.

21 Most economic historians today would still agree with David Hume that "what depends upon a few persons is, in great measure, to be ascribed to chance, or secret and unknown causes; what arises from a great number may often be accounted for by determinate and known causes" (Hume [1742] 1985: 112). 
What incentivized the creators of knowledge was an institution that granted "credit without profit." Priority rights were the equivalent of ownership for intellectual innovations. The creator would earn credit as the rightful discoverer of some natural regularity or phenomenon, or the originator of a new idea. Such priority rights did not include the right to exclude others from using it. To the contrary, the originator wanted others to use it and mention it, as long as he or she was credited by other members of the community as the original innovator. A highly successful intellectual innovator would have her or his name associated with the new idea so that the idea and its progenitor become a dyad as "Boyle's Law" or a "Poisson process," and thus while the progenitor does not own the new idea it is supposed to be attributed to its creator who will therefore gain in terms of reputation (Dasgupta and David, 1994). ${ }^{22}$

For this kind of mechanism to work, what is needed is a community and a language that recognize these reputations and acknowledge the credit that the creators of intellectual innovations have earned. The development that changed history is that such a community emerged in early modern Europe in the form of the "Republic of Letters." The Respublica Litteraria, as it was known to its early members, was a network of scholars and intellectuals, connected through printed books and correspondence, who exchanged ideas and knowledge across national and religious boundaries. It was thus a virtual community, held together by informal norms and rules. The Republic of Letters is distinctly not a historical construct: it was widely recognized by literate people at the time who regarded themselves as "citizens" of the Republic. The incentive mechanism was driven by reputation. For a philosopher, a physician, or a scientist to succeed, he or she had to gain the respect of peers. Despite the fact that the Republic of Letters was not part of any formal political entity it qualifies in every respect as an institution, in that it set the rules of the game and the incentives that drove economic agents. Those such as Clark, 2007 who minimize the role of institutions in the "Great Enrichment" fail to recognize its role in the Scientific Revolution and the Enlightenment.

Reputation was, of course, valuable for its own sake. Shocking as it may sound, intellectuals in the 17th century had egos and vanity much like their counterparts in the 21st century. Fame was sought even if it came without fortune. ${ }^{23}$ All the same, reputation was important because it was correlated with prestigious patronage appointments, the kind of jobs that most would-be academics dreamed about. The world of learning and scholarship of early modern Europe depended

22 In modern economics this idea has been applied widely, not just by the use of dyads such as the "Lucas Critique" and the "Arrow Theorem" but even more so by the use of adjectives such as "Schumpeterian dynamics" and "Samuelsonian economics."

23 Even such a wealthy scientist as Robert Boyle eventually became annoyed by people using his work without attribution and instructed Henry Oldenburg, the secretary of the Royal Society, to produce a catalog of his writings to secure his intellectual property rights in this research (Hunter, 2009: 190; Shapin, 1994: 183). 
on the patronage system, in which powerful and rich people protected and encouraged talented and creative individuals (David, 2008; Feingold, 1984: 190; Westfall, 1985). Being a court-philosopher and advisor to the prince or king, such as Galileo or Leibniz, a tutor to royalty like Descartes, the occupier of a remunerative sinecure like Newton's at the Royal Mint, or a court physician like the French doctor and polymath Pierre-Michon Bourdelot (1610-85), was regarded as the peak of success that scholars and intellectuals could hope to achieve. Others, like Christiaan Huygens and Giovanni-Domenico Cassini, were appointed to the French Royal Academy, replete with a nice pension. To attain this, they had to impress their peers, have their letters and books read and cited, and gain name recognition throughout the transnational Republic of Letters.

Equally important was the decline in negative incentives. Conventional wisdom and entrenched intellectual interests have a way of fiercely defending their positions by declaring dissenting voices as "apostasy" and "heresy" and persecuting such innovators as criminals and subversives. Intellectuals thinking outside the box and criticizing venerable positions held for generations were rarely popular. In many societies, including Ming and Qing China, the Islamic Middle East, and Jewish communities before 1750, dissenting voices were stifled and suppressed, and novelty was allowed only if it conformed to the constraints imposed on it by conventional wisdom. Suppression of new intellectual innovations began to fall apart in early modern Europe, despite the spectacular cases of Miguel Servetus, Giordano Bruno, and Galileo. This was not so much because Europeans became miraculously more enlightened and tolerant (though there was some of that as well), as a massive coordination failure among the oppressive and reactionary powers of Europe, who were at each other's throats too much to formulate coordinated policies against heretics.

European intellectuals learned to play the great powers against one another in various ways: to avoid censorship they published abroad, as was the case with Galileo's "banned” books, that were smuggled out of Italy and published in Protestant cities, such as the Discorsi that was published in Leiden in 1638 and the Dialogo, republished in Strasbourg in 1635. If necessary, they could and did move to a more welcoming place, precisely because scholarly reputations were transnational. Many did, of course, none more so than Paracelsus, the iconoclastic 16th-century Swiss doctor who made it his life's mission to debunk Galenian medicine and the Moravian philosopher Jan Comenius. ${ }^{24}$ Other ways of playing the great powers against one another were available. The unruly Dominican friar Tommaso Campanella spent 27 years in a Neapolitan prison,

24 Pierre Bayle (1647-1707), a highly critical and skeptical French intellectual, was one of central figures of the Republic of Letters. He converted from Catholicism to Calvinism and eventually fled to Rotterdam. The publisher of the newsletter Nouvelles de la République des Lettres (from 1684) printed it in his relatively safe abode in Holland, while his works were burned at the stake in France (which greatly increased their popularity); less innocuously, his brother was arrested in France faute de mieux and died in jail. See Labrousse (1983: 28). 
but because he was under the protection of the Habsburg Emperor Rudolf, his conditions were apparently sufficiently benign for him to write seven books while in prison. After his release he made his way to Paris, where he was celebrated and awarded a royal pension, no doubt as an enemy of the Spanish Habsburgs.

In short, political fragmentation, or the "States System," as Eric Jones (1981) has famously termed it, is often credited with restraining European rulers in a variety of ways even if it was far from a sufficient condition for sustained technological progress. The most important of those constraints was their inability to suppress intellectual innovation. After 1650, such attempts were little more than window-dressing. Radical writers from Spinoza down were denounced and censured, but any serious attempt to prosecute them was symbolic at worst. Diderot's three-month prison term in Vincennes for publishing his Letter on Blindness serves as an example. ${ }^{25}$ Most rulers in Europe realized the futility of clamping down on dissident thought in their nations and indeed many of them, known as enlightened despots, concluded that if they could not beat them, they should join them. A new age was dawning.

\section{Extrinsic and intrinsic motivations}

Focusing on incentives for scientific and technological progress, in the past as well as in the present, misses out on the fact that much original and creative research arises from intrinsic motivation. That is to say, the work itself may have high and positive utility and would be carried out even in the absence of any material or other incentives. Subject to a minimum consumption constraint, creative intellectuals would work, research, and write without any obvious material incentives. In practice, only a few of the major figures of the Scientific Revolution could be thought to be altogether indifferent to material motives. Most of them, as noted, depended on patronage to survive and wanted to be around royal or aristocratic courts for their social status and prestige.

Yet creative people in the upper tail of the human capital and talent distributions have odd utility functions, and recognizing this fact should condition the search for additional motives and incentives in creating new useful knowledge. The norms prevalent in the communities in which new knowledge was created may have driven some intellectuals toward intellectual innovation without any obvious material incentives. Despite the often-heard notion that economists think that most economic actions are driven by self-interest and greed, many of them have thought long and hard about what happens when people are motivated by "intrinsic motives," that is, they carry out economic

25 Iconoclastic authors, such as the radical French philosophe Julien La Mettrie were made to feel uncomfortable, a long way from Giordano Bruno's burning at the stake. La Mettrie first moved to the Netherlands after his materialist views of the human soul annoyed the French, and when his outrageous views caused him to wear out his welcome even in tolerant Holland, he was appointed to the court of Frederick the Great in Potsdam. 
actions without any obvious material incentives (e.g. Besley and Ghatak, 2008). In the setting of a firm, such incentives make sense if they are low-cost for the owner and if they stimulate effort in areas in which output is hard to measure and verify.

As pointed out by Kreps (1997), the distinction between intrinsic motivation and status incentives can be fairly tricky. Kreps notes that in most employment situations (and that covers the bulk of the citizens of the Republic of Letters) it is hard to detect intrinsic motivation. He notes that "what is called intrinsic motivation may be (at least in part) the worker's response to fuzzy extrinsic motivators, such as fear of discharge, censure by fellow employees, or even the desire for coworkers' esteem." It is the latter, more than anything, that drove the Republic of Letters, although here "coworkers' esteem" should be interpreted as "the opinion of other scientists and intellectuals." Reputations, then, led to commissions, appointments, and pensions from wealthy and powerful patrons and were of course also desirable for their own sake.

Intellectual and technological innovation are inherently hard to incentivize for obvious reasons beyond the obvious ones of appropriability: the output is uncertain and often unexpected, and the inputs contain different ratios of perspiration and inspiration, as well as a great deal of randomness, background knowledge, and dexterity. ${ }^{26}$ The difficulty with vague ex ante criteria is that they are seriously in danger of moral hazard, and invite cheating and corruption. As Kreps notes, however, such problems can often be mitigated by peer evaluation and working in small groups, two conditions that were abundantly met in the early modern Republic of Letters.

Adam Smith's Theory of Moral Sentiments [(1759) 1976], as is by now well understood, showed a much wider insight than the somewhat limited view that some modern economists have of how he saw human motivation. Adam Smith surely saw that self-love and the desire to earn income were important elements in human behavior, but as Sen (2010), for instance, has emphasized, this was never sufficient. Smith points out:

To what purpose is all the toil and bustle of the world ... the pursuit of wealth, of power, and preeminence? Is it to supply the necessities of nature? What are the advantages [then] by that great purpose of human life which we call bettering our condition? ... It is the vanity, not the ease of the pleasure, which interests us. But vanity is always founded upon our belief of our being the object of attention and approbation.

Smith does not dismiss extrinsic motivation, in the sense that ambitious people want to build a reputation among their peers for material security, but extends the idea of extrinsic motivation to a realm beyond material gain: a reputation

26 As Kreps points out (1997: 361), “When tasks are ambiguous and creativity is valuable, it is hard to say ex ante what should be done. Opportunistic responses to contingencies that arise are better than responses made to maximize some formula specified ex ante.” 
among one's group of reference matters for its own sake. Accumulating wealth, Smith notes in this famous passage, was not really about increasing one's comforts in life:

The rich man glories in his riches, because he feels that they naturally draw upon him the attention of the world ... Everybody is eager to look at him ... His actions are the objects of the public care. Scarce a word, scarce a gesture can fall from him that is altogether neglected. In a great assembly he is the person upon whom all direct their eyes ... It is this, which ... renders greatness the object of envy and compensates ... all that toil, all that anxiety, all those mortifications which must be undergone in the pursuit of it. (Smith [1759] 1976, pp. 50-1)

This passage might well apply to Nobel Prize winners, the holy grail of academe. ${ }^{27}$

A small but important literature in economics has focused on non-monetary awards to individuals who make outstanding contributions to society and the institutions that govern them (for a survey see Frey and Gallus, 2015). It raises a number of important questions, such as the relative importance of monetary versus pure honorary prizes, as well as whether they stimulate further effort by the winning or create a "rest-on-your-laurels" effect that reduces incentives after the award. As a high-powered incentive such prizes are a blunt instrument, since there is rarely a correlation between the economic value of a scientific contribution (even in the few cases that such a value can be measured) and the value of the award. Furthermore, because awards are normally discretionary (that is, not linked to a specific predetermined goal), they tend to be vulnerable to complaints about judges' conservatism, cronyism, arbitrariness, and bias. ${ }^{28}$ There is also the notion - as prevalent in scientific and technological creative work as it is in the humanities and social sciences - that the existence of awards biases the nature of work to please the expected criteria of the judges (instead of what the market may desire). The effect of prizes and awards on subsequent work seems fairly small (and negative in the case of the Fields medal in mathematics), but this seems a fairly minor quibble even if we can correct for selection bias.

Among intellectual innovators in the academic world, one of the oldest and most effective forms of honoring success is the endowed named chair, a practice already found in the ancient world in which Marcus Aurelius endowed some chairs in philosophy in the 2nd century AD (Frede, 2013). The practice was

27 It is indeed telling that in 2003, one of the co-inventors of MRI diagnosis, Raymond Damadian, was denied the Nobel Prize in Medicine and Physiology, which was awarded to two other scientists who had contributed to the invention. Despite Damadian's immense wealth, he felt deeply slighted, and took out full page ads in a number of newspapers demanding that the decision be revisited. It may be added that Damadian had already been honored in many other ways, including the National Medal of Technology and the Lemelson-MIT prize for lifetime achievement.

28 This is particularly the case with awards for arts and literature, especially the Nobel Prize for literature. It is telling that some of the most influential literary figures of $20^{\text {th }}$-century literature did not win the prize, while quite a few marginal writers did. 
revived in early modern Europe, with the emergence of the Republic of Letters. A key figure in this regard was Lady Margaret Beaufort, the mother of the first Tudor king Henry VII, who in 1502 established the Lady Margaret's professorship of divinity at the University of Cambridge and a lectureship in divinity at Oxford. A few years earlier the first Regius professorship had been endowed in Aberdeen, and Henry VIII established the first ones in England, among others in Law, Greek, and Medicine. The Lucasian chair in mathematics at Cambridge was the first privately endowed chair, per Henry Lucas' will, in 1663. Isaac Newton was the second holder of the chair and held it for 33 years. It is still considered to be one of the most prestigious academic chairs in the world.

The problem with identifying the exact effect of the existence of endowed chairs, membership in honor societies, honorary doctorates, book prizes, and other academic awards on ex ante work is of course that the incentive also motivates the work of people who do not win any awards and are thus disappointed. Indeed, the welfare costs of such disappointments should be subtracted from the consumer surplus generated by advances in useful knowledge. Yet at the same time, whether one wins a prize or not, intellectual innovators experience a sense of "warm glow" for having contributed to human well-being and progress by solving a well-defined high-priority social problem. ${ }^{29}$ Such a drive to do good for others by solving an urgent social need, perhaps more often declared than was truly the case, is still an extrinsic if elusive motive. ${ }^{30}$ It is interesting to note that in the 18th century the areas affected by the Industrial Revolution faced a number of well-defined and well-focused problems that were widely understood to require a solution. Each of these problems was solved by a single or very few individuals, each of whom earned considerable fame in his age. Of those, the examples of Edward Jenner and the Montgolfier brothers, who defeated long-standing challenges that had occupied the best minds of the age, stand out. ${ }^{31}$ But there were quite a few others: John Harrison who (almost) single-handedly solved the problem of measuring longitude at sea; Henry Cort,

29 Such "warm glow" surely must have been of some consolation to Jonas Salk and Albert Sabin, who never won a Nobel Prize for their work on Polio vaccination, though the foundational work on virology by the Ender group at Harvard on which their discoveries were based was awarded the Nobel Prize in 1954. Yet in 1965 Salk was voted a joint resolution by Congress expressing the nation's gratitude to him and President Lyndon B. Johnson called him to the White House to congratulate him personally.

30 René Descartes noted:

I believed that I could not keep them [my notions concerning physics] concealed without greatly sinning against the law which obliges us to procure ... the general good of mankind. For they caused me to see that it is possible to attain knowledge which is very useful in life ... and thus render ourselves the master and possessor of nature. (Descartes [1641] 2005: 50)

But the cynical economist tends to suspect that besides morality and ideology, there may also have been material or other selfish motives.

31 The achievement of the Montgolfier brothers was recognized by the elevation of their father into the nobility in 1783 (perhaps not the best time in French history to join the First Estate). Jacques-Étienne was inducted into the French Academy of Sciences in 1796, and Joseph Michel was given the Legion of 
who cracked the technological bottleneck of converting pig iron into wrought iron, something other iron masters had been struggling with for decades; James Hargreaves, the first to build a machine that definitely replaced human fingers in the spinning process with metal draw bars and mechanical spindles; Thomas Newcomen and John Smeaton who built machinery that helped reduce mineflooding. Of those, only Hargreaves and Newcomen died in relative obscurity but their glory was captured by others. ${ }^{32}$

Reputation games, then, are one key to understand what motivated scientists, inventors, and other intellectual innovators. This is of course not to deny that purely altruistic motivations matter, but the two tend to be hard to separate. Consider the case of Humphry Davy, one of the most notable scientists of the early 19th century and, among many other achievements, the co-inventor of the "Miner's Friend," a safety lamp that reduced the risk of coal mine explosions. Davy quite explicitly stated that his motivation was to help prevent mine disasters and save lives, and expressly refused to patent the invention. Yet this did not stop him from engaging in a rather ugly priority dispute with George Stephenson, who had invented a similar device quite independently. Davy argued that an untrained (if ingenious) artisan could not possibly have come up with the idea of the lamp. Be that as it may, it is telling that even here seemingly altruistic motivation was flavored by an ambition to receive reputational credit for an invention that was supposed to benefit mankind. Equally revealing is the case of the Dutch microscopist Anthonie van Leeuwenhoek, a self-taught and able mathematician and a well-to-do and respected draper, who was hired by his city of residence, Delft in the Netherlands, in various positions such as surveyor and inspector of weights and measures. Yet his true interest was the manufacturing and use of microscopes, and he communicated his findings (written originally in Dutch) to the Royal Society in London, which published many of his letters. In 1680 he was elected a Fellow, and clearly this was a source of pride for him. ${ }^{33}$

Not every intellectual innovator played the reputation game as hard as they could. Some of them were eccentric recluses who published their work only rarely and were content to do their research alone and for its own sake. These cases must be seen as the purest examples of intrinsic motivation. An example is the above-mentioned Henry Cavendish, an English chemist in the 18th century, the discoverer of hydrogen, and in some views "without peer in eighteenth century

Honor by Napoleon. Jenner, of course, became a legend in his own time and was awarded an enormous stipend by Parliament in 1815 .

32 Henry Cort died a bankrupt despite being awarded a small government pension $(£ 200$ a year a few years before his death). A petition for the estate of Henry Cort for a financial reward on account of the importance of the invention was denied by Parliament, but the fact that other ironmasters entered a subscription for the benefit of Cort's widow demonstrates that contemporaries were aware of the significance of his invention of the puddling and rolling process.

33 Leeuwenhoek had the fact of his membership in the Royal Society engraved on his tombstone and a painting of him by Jan Verkolje shows him proudly displaying his Royal Society diploma of membership. 
English natural philosophy ... the first after Newton to possess mathematical and experimental talents at all comparable to Newton's" (McCormmach, 2008: 159). While he published a number of things, many of his most important findings remained unpublished and discovered only many years after his death. Newton himself had to be persuaded by Edmund Halley to publish the third volume of Principia and in many ways he does not fit the picture of a person driven by extrinsic motivation. During his so-called "years of silence" at Trinity College prior to the publication of Principia in 1687, Newton worked on a large number of projects that seem understandable only through pure intrinsic motivation. Among them were unpublished essays on theology, a detailed plan of the Solomonic Jerusalem temple based on the scriptures, and an enormous number of writings on chemical problems, which were barely known in his lifetime (Dobbs, 2002).

Curiosity is a form of intrinsic motivation that drives useful knowledge forward. Huff (2011:112) asserts a "curiosity deficit" that explains the difference between Europe and China and places much of his explanation for Europe's leadership on Europeans being more "curious." That argument, however, raises more difficulties than it solves. Wootton (2015: 61n) points out that in the Christian West curiosity was traditionally regarded as a vice and so its transformation from vice to virtue was itself endogenous, a consequence rather than a cause.

But things are not that simple. St. Augustine, to be sure, condemned curiositas and included it in his list of vices. ${ }^{34}$ Thomas Aquinas, however, who is often held equally responsible for the condemnation of "curiosity," did make some fine distinctions between the kinds of knowledge that were virtuous to pursue and those that were not. ${ }^{35}$ The aversion to new knowledge for its own sake was thus already weakening in the later middle ages, but it was still powerful and can still be found in Erasmus. That said, there is no question that early modern Europe experienced a cultural transformation that made curiosity a virtue, especially for the elites. The Renaissance courts and academies proudly paraded their curiosity and saw the display of new knowledge as a symbol of the superiority and power of the ruling classes. This new attitude was particularly manifest in the proto-museums known as "curiosity cabinets," which displayed exotic animal and plant specimens and antiques (Eamon, 1994, pp. 223-4).

From St Augustine and even St Thomas it was a long way to Francis Bacon, who insolently warned his readers in The Great Instauration not to fall into

34 St Bernard of Clairvaux (1090-153), an influential monastic reformer, promoted curiosity to one of the seven deadly sins as a subspecies of "lust" (Daston, 1995: 393).

35 Aquinas (1947, questions 166-7) viewed the intrinsically motivated search for knowledge favorably within limits. As long as the philosophers do not seek truth "to assail the faith" or study "to know the truth above the capacity of his own intelligence, since by so doing men easily fall into error," he was willing to allow a certain level of curiosity. He distinguished between "studiositas" and "curiositas," the former being a virtue, the latter a vice under certain circumstances. 
the error of thinking "that the inquisition of nature is in any part interdicted or forbidden," and cited with approval Proverbs 25:2, which stated that "it is the honor of God to conceal a thing and the honor of kings to investigate them" (my translation from the Hebrew) (Bacon [1620] 1999, pp. 74-5). While Bacon still warned that the "true end of knowledge" should not be "for the pleasure of the mind," research of any kind was turned into a virtuous activity. Hobbes, famously, defined curiosity as the desire to know the causes of things, and noted:

such as is in no living creature but Man; so that Man is distinguished, not onely by his Reason; but also by this singular Passion from other Animals; in whom the appetite of food, and other pleasures of Sense, by praedominance, take away the care of knowing causes ... is a Lust of the mind, that by a perseverance of delight in the continuall and indefatigable generation of Knowledge, exceedeth the short vehemence of any carnall Pleasure. (Hobbes ([1651] 1929: 44)

Clearly he realized that research was fun - an intrinsic motivation indeed. By the mid-17th century, this had become an acceptable view. As Daston phrases it, "moralists continued to thunder away against such frivolous and potentially dangerous interests ... but the decibel level of their complaints suggests that by the late seventeenth century they were on the defensive" (Daston, 2005: 37).

Modern historical scholarship has, indeed, recognized the rise of curiosity as a salient feature of modernity. In their canonical work, Daston and Park (1998, pp. 303-4) quote from Newton's 1672 letter to Henry Oldenburg, then secretary of the Royal Society, about how he had started to investigate the relation between the length and the breadth of the colored spectrum of light as a "pleasing divertissement" but then the disproportion [between them] struck him as "so extravagant that it excited me to a more than ordinary curiosity of examining from whence it might proceed[.]" Daston and Park stress that this sentiment had become commonplace by that time: "Musing admiration, startled wonder, then bustling curiosity - these were the successive moments of 17th-century clichés describing how the passions impelled and guided natural philosophical investigations." By the mid-18th century "wonder" had declined, but "curiosity, for centuries reviled as a form of lust or pride, became the badge of the disinterested and dedicated naturalist." In that sense, curiosity had become the intrinsic motivation par excellence. Curiosity, however, was confined to the educated elite, and scholarly writing created a quaint contrast between the "curious" and the "vulgar" (Daston, 1995: 402). Here too, cultural change was driven by a vital few.

\section{Concluding remarks}

Modern economic growth is a complex phenomenon that has depended on social, political, and technological change. As far as technology is concerned, there can be little doubt that it was driven by upper-tail human capital, and was primarily 
a top-down phenomenon. A relatively small percentage of natural philosophers and artisans dragged along the rest, often willy nilly. An examination of the motives driving these vital few pushing the scientific and technological envelopes reveals a mixture of material and other motives. They include a fierce competition for patronage positions and the recognition that drove that competition. They also included the desire for honor and prestige, and an altruistic desire to improve the lot of others. Finally, there were "intrinsic" motives, of which curiosity and a religious desire to illustrate the greatness of the creator figured prominently.

Yet such motives can only have an effect if they are channeled and organized through institutions, and here the European case clearly was exceptional. Its political fragmentation and its intellectual unity created a unique competitive environment, in which incentives to create useful knowledge were exceptionally strong. In this world, a small minority created the knowledge that made the new world. This minority consisted of people who created new propositional knowledge (science) and those who created new prescriptive knowledge (technology). Europe created the institutions in which these two groups communicated and exchanged ideas. Many individuals, of course, straddled both groups and would be difficult to pigeon-hole as scientists or inventors.

In assessing the role of institutions in what is becoming known as the "Great Enrichment," it is important to avoid seeing institutions narrowly as involving national political power and property rights. While the rule of law and contract enforcement may have been of great importance, this approach cannot fully explain modern economic growth because it has no good explanation of why useful knowledge exploded the way it did in the 18th century. Nor can we see the reasons for continued growth of useful knowledge in our own age. Yet as long as some global digitalized version of the Republic of Letters is still governing today's fragmented world, it is hard to see how the continued march of technologically driven economic progress can be stopped, except by catastrophic institutional failure.

\section{References}

Acemoglu, D. and J. Robinson (2006) "De Facto Political Power and Institutional Persistence," American Economic Review 96(2), pp. 325-30.

Allen, R. C. (2009) The British Industrial Revolution in Global Perspective. Cambridge: Cambridge University Press.

Aquinas, T. (1947) The Summa Theologica (Benziger Bros edition). Translated by Fathers of the English Dominican Province. Available at http://dhspriory.org/thomas/ summa/SS.html (accessed July 20, 2017).

Bacon, F. ([1620]1999) The Great Instauration. Reprinted in Selected Philosophical Works, edited by Rose-Mary Sargent. Indianapolis, IN: Hackett Publishing.

Beckert, S. (2014) Empire of Cotton: a Global History. New York: Vintage Books.

Berg, M. (2007) “The Genesis of Useful Knowledge,” History of Science 45/2(148), 123-34. 
Besley, T. and M. Ghatak (2008) "Status Incentives," American Economic Review 98(2), 206-11.

Clark, G. (2007) A Farewell to Alms. Princeton, NJ: Princeton University Press.

Coleman, D. C. and C. MacLeod (1986) “Attitudes to New Techniques: British Businessmen, 1800-1950," Economic History Review (New Series) 39(4), 588-611.

Dasgupta, P. and P. A. David (1994) “Toward a New Economics of Science," Research Policy, 23(5), 487-521.

Daston, L. (1995) “Curiosity in Early Modern Science,” Word and Image 11(4), 391-404.

Daston, L. (2005) "All Curls and Pearls: a review of Neil Kenny, 'The Uses of Curiosity in Early Modern France and Germany." London Review of Books, June 23, pp. 37-8.

Daston, L and K. Park (1998) Wonders and the Order of Nature, 1150-1750. New York: Zone Books.

David, P. A. (2008) “The Historical Origins of 'Open Science': An Essay on Patronage, Reputation and Common Agency Contracting in the Scientific Revolution," Capitalism and Society 3(2), 1-103.

De la Croix, D. and O. Licandro (2015) "The Longevity of Famous People from Hammurabi to Einstein," Journal of Economic Growth 20(3), 263-303.

Descartes, R. ([1641]2005) Discourse on Method and Meditations on First Philosophy. Translated by Elizabeth Haldane. Stilwell, KS: Digireads.

Dobbs, B. J. T. (2002) The Janus Faces of Genius: The Role of Alchemy in Newton's Thought. Cambridge: Cambridge University Press.

Eamon, W. (1994) Science and the Secrets of Nature. Princeton, NJ: Princeton University Press.

Epstein, S. R. (2008). "Craft Guilds, the Theory of the Firm, and the European Economy, 1400-1800.” In S. R. Epstein and M. Prak (eds), Guilds, Innovation and the European Economy, 1400-1800. Cambridge: Cambridge University Press, pp. 52-80.

Evans, R. J. W. (1973) Rudolf II and His World. Oxford: Oxford University Press (1997 edition).

Fara, P. (2002) Newton: The Making of a Genius. New York: Columbia University Press.

Feingold, M. (1984) The Mathematician's Apprenticeship: Science, Universities and Society in England 1560-640. Cambridge: Cambridge University Press.

Frede, D. (2013) “Alexander of Aphrodisias," The Stanford Encyclopedia of Philosophy, edited by Edward N. Zalta. Available at http://plato.stanford.edu/archives/ sum2013/entries/alexander-aphrodisias/ (accessed July 20, 2017).

Frey, B. and J. Gallus (2015) "Towards an Economics of Awards," Journal of Economic Surveys. DOI: 10.1111 /joes.12127.

Greif, A. (2005) Institutions and the Path to the Modern Economy: Lessons from Medieval Trade. Cambridge: Cambridge University Press.

Greif, A. and J. Mokyr (2016) "Institutions and Economic History: A Critique of Professor McCloskey," Journal of Institutional Economics 12(1), 29-41.

Hobbes, T. ([1651]1929) Leviathan. Oxford: Clarendon Press.

Houghton, W. E., Jr. (1942) “The English Virtuoso in the Seventeenth Century, pts. I and II," Journal of the History of Ideas 3(1), 51-73, 190-217.

Huff, T. (2011) Intellectual Curiosity and the Scientific Revolution. Cambridge: Cambridge University Press.

Hughes, J. R. T. (1986) The Vital Few: the Entrepreneur and American Progress. Expanded Edition. Oxford: Oxford University Press. 
Hume, D. ([1742]1985) "Of the Rise and Progress of the Arts and Sciences." In D. Hume, Essays: Moral, Political and Literary, edited by E. F. Miller. Indianapolis: Liberty Fund, pp. 111-37.

Hunter, M. (1989) Establishing the New Science: the Experience of the Early Royal Society. Woodbridge, UK: Boydell Press.

Hunter, M. (2009) Boyle: Between God and Science. New Haven, CT: Yale University Press. Jacob, M. C. (1997) Scientific Culture and the Making of the Industrial West (2nd edn), New York: Oxford University Press.

Jones, E. L. (1981) The European Miracle. Cambridge: Cambridge University Press.

Kelly, M. and C. Ó Gráda (2017) “Adam Smith, Watch Prices, and the Industrial Revolution,” Quarterly Journal of Economics, forthcoming.

Kreps, D. M. (1997) "Intrinsic Motivation and Extrinsic Incentives," American Economic Review 87(2), pp. 359-64.

Labrousse, E. (1983) Bayle, translated by Dennis Potts. Oxford: Oxford University Press.

Lowengard, S. (2006) The Creation of Color in Eighteenth-Century Europe. New York: Gutenberg-ebooks. Available at www.gutenberg-e.org/lowengard/index.html, accessed October 4, 2010.

MacLeod, C. (2007) Heroes of Invention: Technology, Liberalism and British Identity. Cambridge: Cambridge University Press.

McCloskey, D. N. (2010) Bourgeois Dignity: Why Economics Can't Explain the Modern World. Chicago: University of Chicago Press.

McCormmach, R. (2008) “Cavendish, Henry.” In C. C. Gillispie, ed., Complete Dictionary of Scientific Biography (vol. 3). Detroit: Charles Scribner's Sons, pp. 155-9.

Meisenzahl, R. R. and J. Mokyr (2012) "The Rate and Direction of Invention in the British Industrial Revolution: Incentives and Institutions.” In S. Stern and J. Lerner (eds), The Rate and Direction of Innovation. Chicago: University of Chicago Press, pp. 443-79.

Mokyr, J. (2005) "Long-term Economic Growth and the History of Technology." In P. Aghion and S. Durlauf (eds), Handbook of Economic Growth. Amsterdam: Elsevier, pp. 111380 .

Mokyr, J. (2007) “Knowledge, Enlightenment, and the Industrial Revolution: Reflections on Gifts of Athena". History of Science 45(148) 185-96.

Mokyr, J. (2009) The Enlightened Economy. New York and London: Yale University Press.

Mokyr, J. (2017) “The Market for Ideas and the Great Enrichment.” Unpublished manuscript, presented at the Hoover Institution conference on "Restoring Prosperity," February.

Musson, A. E. and E. Robinson (1969) Science and Technology in the Industrial Revolution. Manchester: Manchester University Press.

Ostrom, E. and C. Hess (2007) “A Framework for Analyzing the Knowledge Commons.” In C. Hess and E. Ostrom (eds), Understanding Knowledge as a Commons. Cambridge, MA: MIT Press, pp. 41-81.

Pacey, A. (1975) The Maze of Ingenuity: Ideas and idealism in the Development of Technology. New York: Holmes and Meier.

Reynolds, T. S (1983) Stronger Than a Hundred Men: A History of the Vertical Water Wheel. Baltimore: Johns Hopkins University Press.

Sen, A. (2010) "The Economist Manifesto," New Statesman, April 23.

Shank, J. B. (2008) The Newton Wars and the Beginnings of the French Enlightenment. Chicago: University of Chicago Press.

Shapin, S. (1994) A Social History of Truth. Chicago: University of Chicago Press. 
Smith, A. ([1759]1976) The Theory of Moral Sentiments, edited by D. D. Raphael and A. L. Macfie. Oxford: Oxford University Press.

Smith, A. ([1762-3] 1978) Lectures on Jurisprudence, edited by R. L. Meek. Oxford: Oxford University Press.

Squicciarini, M. and N. Voigtländer (2015) Human Capital and Industrialization: Evidence from the Age of Enlightenment, Quarterly Journal of Economics 130(4), 1825-83.

Tomory, L. (2012) Progressive Enlightenment: The Origins of the Gaslight Industry, 17801820. Cambridge, MA: MIT Press.

Westfall, R. S. (1985) "Science and Patronage: Galileo and the Telescope," Isis 76(1) 11-30.

Wootton, D. (2015) The Invention of Science: A New History of the Scientific Revolution. London: Allen Lane. 